large number of Cycadece included in the genus Zamia, with two aberrant forms, Ceratozamia and Dion. The Zamias have short dividing stems, or tall and slender simple ones, and the scales of the cones are simply peltate, and arranged in vertical order. A stem from the Lias, which is the oldest fossil which can certainly be referred to the Order (Yatesia), should probably be placed near this genus; and the numerous cones from the Oolite and Wealden, though exhibiting a different arrangement of the scales, are probably more nearly related to this genus than to any living form. Besides these, trunks of Cycads occur in the Isle of Portland, and in later formations in the south of England, which differ from any living forms in the structure of the stem, and still more in the character of the fruits. The seeds are buried in fleshy cushions, borne in the axils of the leaves. These plants, which have been named Bennettites, represent an extinct group bearing the same relation to the living forms that the Yew does to the other Coniferæ. A still more anomalous group of plants, known as Williamsonia, is met with in the Oolites of Yorkshire, and beds of similar age elsewhere, with stems and leaves like those of this Order; the stamens of which appear to have been borne naked round a shortened fleshy axis, and the seeds on the surface of a radiating disc. These present such strange anomalies that it is not to be wondered at that different views are entertained as to their affinities.

After a cordial vote of thanks to Mr. Carruthers the party separated.

\title{
VISIT TO THE GEOLOGIOAL MUSEUM OF DR. J. CHANING PEARCE, AT THE MANOR HOUSE, BRIXTON.
}

(Report by H. B. WoOdWARd, F.G.S.)

Although the name of Chaning Pearce is familiar to geologists who have worked at the Oolitic formations of the West of England, yet few, probably, are aware that the collection of fossils made by the late Mr. Pearce is at the present day accessible to students throngh the courtesy of his son, Dr. J. Chaning Pearce, F.G.S.

This collection, which numbers upwards of 5,000 specimens, and is especially rich in Mesozoic fossils, was formed mainly during the years 1816-47, by Mr. Joseph Chaning Pearce. Writing in 1848, 
De la Beche described it as "one of the finest private collections of organic remains in this country," and the description would equally apply now. In an old Visitors' Book one may read the names of Sedgwick, Mantell, Buckland, De la Beche, Joun Phillips, and other distinguished geologists who had visited Mr. Pearce's Museum ; the names also of Gaudry, Hébert, and Renevier, showed that some continental geologists also were acquainted with the collection.

The history of its formation is interesting, for although commenced in 1816, Chaning Pearce was then only five years of age, having been born at Bradford, in Wiltshire, on the 18th July, 1811. Some account of him has been furnished by De la Beche,* who says :- " His deeire to collect organic remains commenced with his infancy, and it was with difficulty that his nurse could withdraw him from the heaps of stone or clay near Bradford, whence he obtained and brought to bis father various fossils. $\mathrm{He}$ probably acquired this desire from his parent, who, before him, was accustomed to search for specimens of the Apiocrinites, commonly known as the Bradford encrinite." Chaning Pearce ultimately qualifed as a surgeon, and joined his father in a medical practice in and around Bradford. This he relinquished in 1845, after being twelve years actively engaged in his profession, but throughout the whole of this time, and for the short remainder of his life, he availed himself of every opportunity of adding to his collection. While it is especially rich in the fossils of the Oxford Clay, Forest Marble, Bradford Clay, and Great Oolite, nearly every formation, from the most recent to the Llandeilo Flags, is represented, many of the specimens having been obtained by exchange. Mr. Pearce, who settled at Montague House, Lambridge, near Bath, there built a convenient museum for his extensive collections-and there it was that he received and welcomed any visitor who took an interest in geology. He died, however, in 1847, when not quite 36 years of age.

Mr. Rudler, the Director, drew the notice of the Members of the Association to some of the fossils to which Mr. Pearce had devoted especial attention. When the Great Western Railway was in course of construction through Wiltshire, a fine series of fossils was obtained from the cuttings in the Oxford Clay at Christian

* 'Address to Geol. Soc.,' 1848; and Charlesworth, 'London Geol. Journal,' No. iii, p. 127, 
Malford, near Chippenbam. Among these were many Cephalopoda -apparently Belemnites, - of which the soft parts were unusually well preserved. By a careful study of these Mr. Pearce determined that certain of the forms presented characters sufficiently distinct to entitle them to a separate generic title, and he proposed the name Belemnoteuthis, which is now generally adopted.*

Attention was also called to the fine collection of Ammonites from the Oxford Clay.

Mr. Rudler then made some remarks on the "Bradford encrinite" (Apiocrinites rotundus or Parkinsoni) known in the district as "peg-tops" and "coach-wheels"-no more perfect specimens of which are probably to be seen in any other collection. Mr. Pearce had in 1833 read a paper on these fossils before the Geological Society, and the beautiful drawings with which it was illustrated were now produced. Again, in 1843, Mr. Pearce had drawn attention to the various modes of attachment among the Crinoidea, separating those which were locomotive from the nonlocomotive. The Apiocrinites belong to the latter group, and specimens were found of the base or foot firmly adhering to the rock, in its natural position.

Several specimens of Ichthyosaurus next attracted attention, and one in particular was pointed to by the Director as furnishing evidence which had led Mr. Pearce to conclude that the reptile was viviparous.

It was, however, impossible to do more than glance generally at the numerous cabinets of specimens, or at the larger fossils, the Saurians, huge Ammonites, and others which were affixed to the walls, or displayed on shelves. Owing to the wealth of the collection, Mr. Rudler was obliged to confine his observations to the organic remains of the Lias and Oolites.

The following is a record of the published geological papers by Mr. J. Chaning Pearce:-

1833.- On the Oolitic Formation and its Contents, as occurring in a Quarry at Bearfield, near Bradford, Wilts.'-' Proc. Geol. Soc.,' Vol. i, pp. 484-485.

1842.- ' On the Mouths of Ammonites, and on Fossils contained in laminated beds of the Oxford Clay, discovered in cutting the Great Western Railway, near Christian Malford, in Wiltshire'Ibia. Vol. iii, pp. 592-594.

* 'Proo. Geol. Soc.' Vol. ii, p. 593 ; and 'London Goological Journal,' No. ii, p. 75. 
1843.- ' On the Locomotive and Non-locomotive powers of the Family Crinoidea.'-Ibid., Vol, ir, pp. 159-160.

' On an entirely new form of Encrinite from the Dudley Limestone.'-Ibid., Vol. iv, p. 160.

1847. - ' On the fossil Cephalopoda constituting the genus Belemnoteuthis, Pearce.'-' London Geol. Journal,' No. ii, pp. 75-78.

\section{EXCURSION TO CANTERBURY, RECULVERS, PEGWELL BAY, AND RICHBOROUGH.}

\section{APRIL 6Th AND 7TH, 1885.}

Directors : W. Whitaker, B.A., F.G.S., and G. Dowker, F.G.S., Vice President, East Kent Nat. Hist. Soc.

\section{(Report by The DIREctors.)}

Many of the party began the Excursion on Saturday, April 4, meeting Mr. Whitaker at Selling Station, whence they were led southward along the flank of the wooded Tertiary escarpment, to the high road (Watling Street) from Faversham to Canterbury, seeing on the way pits in the Woolwich Sand, and the remains of a small pit in which the ironstone of the Oldhaven Beds had been worked. From a heap of this stone many casts and impressions of shells were got.

The excursionists, about 25 in number, were most hospitably entertained at luncheon by Mr. John Marten, at Dunkirk House, which is on about the highest ground of the well-marked ridge of the London Clay. They also inspected a collection of flint implements, found by their host in the neighbourhood, as well as one of fossils from the Thanet Beds of the district (including specimens of the peculiar silicified shells and wood that occur in places); and from the top of the iofty tower of the house they enjoyed the fine and extensive view, the leading features of which were alluded to by $\mathrm{Mr}$. Whitaker, from a geological standpoint.

In the afternoon the walk was continued along the Watling Street to Canterbury. This was the road taken by Chaucer's Canterbury Pilgrims, and by all the travellers from London. A halt was made at the spot where the Cathedral first comes into view, and as the road fell to a lower level, reaching the outcrop of beds below the London Clay, some small sandpits were noticed, 